\author{
Michael P. LOMBARDO ${ }^{1,}{ }^{*}$, Patrick A. THORPE ${ }^{1}$, and Sheila COLPETZER ${ }^{1,2}$ \\ ${ }^{1}$ Department of Biology, Grand Valley State University, Allendale, MI 49401, USA \\ ${ }^{2}$ Current address: Charlie Company, DDEAMC, General Delivery, Fort Gordon, GA 30905, USA. \\ *Corresponding author: e-mail: lombardm@gvsu.edu
}

\title{
SOCIAL ENVIRONMENT AFFECTS BEAK COLOR IN CAPTIVE MALE HOUSE SPARROWS PASSER DOMESTICUS
}

\begin{abstract}
Black beak color in male House Sparrows (Passer domesticus) is a secondary sexual characteristic whose expression is directly correlated with testosterone levels. To experimentally determine if social environment affects black beak color and by implication testosterone levels, we housed wild-caught male sparrows either individually $(\mathrm{n}=10)$, "Solo" males, or in the company of two other males ( $n=4$ "Group"s of 3 males), "Group" males, from 26 May - 7 July 2006. We predicted that "Solo" males would lose beak color faster than would "Group" males. We used digital images to monitor beak color once a week starting on 26 May. Beak blackness decreased more quickly and to a greater degree in "Solo" than in "Group" males. These results show that social environment in captivity affected beak color and suggest that male House Sparrows may require physical interactions to maintain breeding season levels of testosterone.

Key words - captivity, House Sparrows, Passer domesticus, testosterone

\section{INTRODUCTION}

Testosterone (T) influences many aspects of the physiology and behavior of birds (Wingfield and Farner 1980, Wingfield and Moore 1987, Wingfield and Farner 1993). In the temperate zone, male $\mathrm{T}$ levels usually increase as day length gets longer and the breeding season approaches (Wingfield and Farner 1993). Increased T stimulates continued growth of the gonads, spermatogenesis, and the development of secondary sexual characteristics (Wingfield et al. 1987). Increased T levels are also associated with increased intensity of male territorial defense, mate attraction, and competition for mates during the breeding season (e.g., Wingfield 1985, Wingfield et al. 1987, Hirschenhauser and Oliveira 2006). The Challenge Hypothesis (Wingfield et al. 1990) argues that $\mathrm{T}$ levels increase when males are exposed to other males, stimulating them to aggressively defend their territories, position in the dominance hierarchy, and mates. Hirschenhauser and Oliveira (2006) showed that many, but not all, experimental tests support the Challenge Hypothesis for birds.
\end{abstract}


Beak color in male House Sparrows (Passer domesticus) is a secondary sexual characteristic whose expression is directly correlated with T levels (Keck 1934, Pfeiffer et al. 1944, Witschi 1961, Haase 1975). Male House Sparrows have black beaks during the breeding season when $\mathrm{T}$ levels are their highest and horn-colored beaks during the non-breeding season when T levels are low (Hegner and Wingfield 1986). We set out to experimentally determine if social environment affects beak color, and by implication T levels, during the breeding season in male House Sparrows. We were interested in pursuing this question because a previous experiment showed that when male House Sparrows were caged individually during the breeding season in auditory and visual, but not physical contact with sparrows of both sexes, their testes atrophied, sperm production declined, and beaks turned from black to horn-colored (Lombardo and Thorpe 2009). These changes suggested that T levels declined during captivity because (a) testes size is positively correlated with circulating T levels (Hegner and Wingfield 1986), (b) sperm production is positively correlated with T levels in birds (Johnson 1986, Wingfield and Farner 1993), and (c) the amount of black on the beak of male House Sparrows was shown by experiments performed decades ago to be a reliable indicator of testicular activity and T levels (Keck 1934, Pfeiffer et al. 1944, Witschi 1961).

We captured wild male House Sparrows during the breeding season and housed them either alone or in groups of three to test whether the change in their beak coloration varied with social environment. We used this experimental design because Hegner and Wingfield (1984) presented evidence implying that social facilitation may be essential for gonadal development in male House Sparrows. Accordingly, we predicted that males housed with other males would retain black beaks for longer than would males housed alone.

\section{STUDY AREA}

We studied 22 male House Sparrows that we captured on the Grand Valley State University campus, Allendale, MI, USA ( $\left.42^{\circ} 57^{\prime} \mathrm{N}, 85^{\circ} 53^{\prime} \mathrm{W}\right)$.

\section{MATERIALS AND METHODS}

We used mist nets and walk-in traps to capture 22 male House Sparrows during May 2006. When each bird was captured, we measured its mass with a Pesola spring scale to the nearest $0.2 \mathrm{~g}$ and used a Sony FD Mavica 2 megapixel digital camera to photograph using ambient light the right side of its beak with a ruler included in the photograph to provide scale. Sparrows were hand-held during photography. We banded each sparrow with a unique combination of plastic colored bands for individual identification.

After preliminary measurements, each bird was put into a cage $(66 \times 27 \times 33 \mathrm{~cm}$; $1.27 \mathrm{~cm}$ bar spacing) with three other male sparrows. Each cage contained two hardwood perches, two plastic cups for food, two plastic cups for water, and two nest 
boxes. Cages were stacked on metal racks so that each rack contained four cages. All cages were in a covered screen tent outdoor aviary $\left(9.29 \mathrm{~m}^{2}\right.$ floor area, $2.44 \mathrm{~m}$ center height) which shaded the sparrows and protected them from rain and biting insects but allowed them to be exposed to natural photoperiods. Nesting materials, food, and water were provided ad libitum. We fed the sparrows a commercial seed mix (KAYTEE Supreme Canary Fortified Daily Blend; crude protein 15\%, crude fat 10\%, crude fiber $10 \%$, moisture $12 \%$ ) periodically supplemented with vitamins (Scott's Petamine Breeding Formula) and grit. We restricted the time we spent at the aviary to reduce the amount of investigator-induced stress on the sparrows. In addition, the aviary was located in a partially hidden location on campus not often frequented by people so as to reduce disturbance.

On 26 May 2006, the sparrows were randomly assigned to one of two different social environments; (a) 10 males were housed individually, hereafter "Solo" males, and (b) 12 males were housed in four replicates of three males housed together, hereafter "Group" males. All birds were housed in cages of $33 \times 27 \times 33 \mathrm{~cm}$. Each "Solo" male was provided with a nest box and nesting material for roosting. "Group" males were provided with two nest boxes and nesting material for roosting. All sparrows, regardless of housing arrangement, were in visual and auditory contact with other sparrows of both sexes housed in nearby cages. Females were housed nearby because a previous study with captive European Starlings (Sturnus vulgaris) demonstrated that even brief exposure to a female could affect T levels in male birds (Pinxten et al. 2003). Cages with "Solo" or "Group" males were randomly distributed on racks in the aviary to control for cage location effects. We measured each male's mass at two week intervals starting on 26 May to monitor male body condition.

We obtained a digital image of the right side of each male's beak at weekly intervals starting on 26 May using the same methods as described above. We later used SCION image analysis software (www.scioncorp.com) to determine the proportion of the beak that was black (i.e., area black $\left(\mathrm{mm}^{2}\right) /$ total beak area $\left.\left(\mathrm{mm}^{2}\right)\right)$ hereafter, beak blackness. Black and non-black areas of the bill were outlined and the software calculated their areas $\left(\mathrm{mm}^{2}\right)$. The analysis tool was calibrated to each individual image by measuring the ruler in each image. To improve repeatability and control potential measurements error only one person (S.C) performed all image analyses.

All but two sparrows that died of unknown causes during the study were released at the end of the experiment on 7 July.

We examined the data for normality and analyzed data using SPSS 12.0 for Windows (SPSS 2002). We performed two-way repeated measures ANOVAs to test for the effects of housing arrangement and sampling week on mass and beak blackness. For "Group" males we performed repeated measures ANOVA to test for cage effects. When preliminary analyses using Mauchly's test of sphericity revealed evidence of significant heterogeneity of covariances we used more conservative Greenhouse-Geisser F (GG-F) 
values to determine the statistical significance of ANOVAs, otherwise we used the traditional ANOVA $F$ test (Kinnear and Gray 2004). We used Pearson correlation coefficients $(r)$ to examine the relationships between mean beak blackness and sampling week. All tests are two-tailed. The probability level for significance was set at $\alpha=0.05$. Values for morphological measures are given as means \pm SD.

\section{RESULTS}

There was no significant difference in mass at capture between males that were eventually assigned to be "Solo" $(27.6 \pm 1.92 \mathrm{~g}, \mathrm{n}=10)$ or "Group" males $(26.5 \pm 1.79 \mathrm{~g}$, $\mathrm{n}=12)(t=1.27, \mathrm{df}=20, P=0.22)$. However, on the day of housing assignment "Solo" males $(27.10 \pm 1.60 \mathrm{~g}, \mathrm{n}=10)$, by chance, weighed significantly more than did "Group" males $(25.25 \pm 1.66 \mathrm{~g}, \mathrm{n}=12)(t=2.65, \mathrm{df}=20, P=0.02)$ (Fig. 1). Social environment significantly affected final mass $\left(F_{1,18}=5.83, P=0.03\right)$, but neither sampling day $\left(G G-F_{1.3,23.9}=2.24, P=0.14\right)$ nor the interaction between the two factors affected final mass $\left(G G-F_{1.4,23.9}=1.23, P=0.30\right)$. Furthermore, mean mass decreased, but not significantly, during the experiment in both "Solo" $(r=-0.94, \mathrm{n}=4, P=0.06)$ and "Group" males ( $r=-0.49, \mathrm{n}=4, P=0.51)$ (Fig. 1).

Beak blackness was significantly affected by sample day $\left(G G-F_{1.3,23.4}=15.35\right.$, $P<0.005)$, social environment $\left(F_{1,18}=5.07, P=0.04\right)$, and the interaction between the two $\left(G G-F_{1.3,23.4}=4.45, P=0.04\right)$. Mean beak blackness significantly decreased



Figure 1. Mean mass of captive male House Sparrows during each sample day for each social environment. Sample 1 = day of housing assignment, 26 May 2006. Mass was obtained biweekly. Means $\pm \mathrm{SD}$ are presented. Trend lines from linear regression of mean mass regressed on day of sampling. 


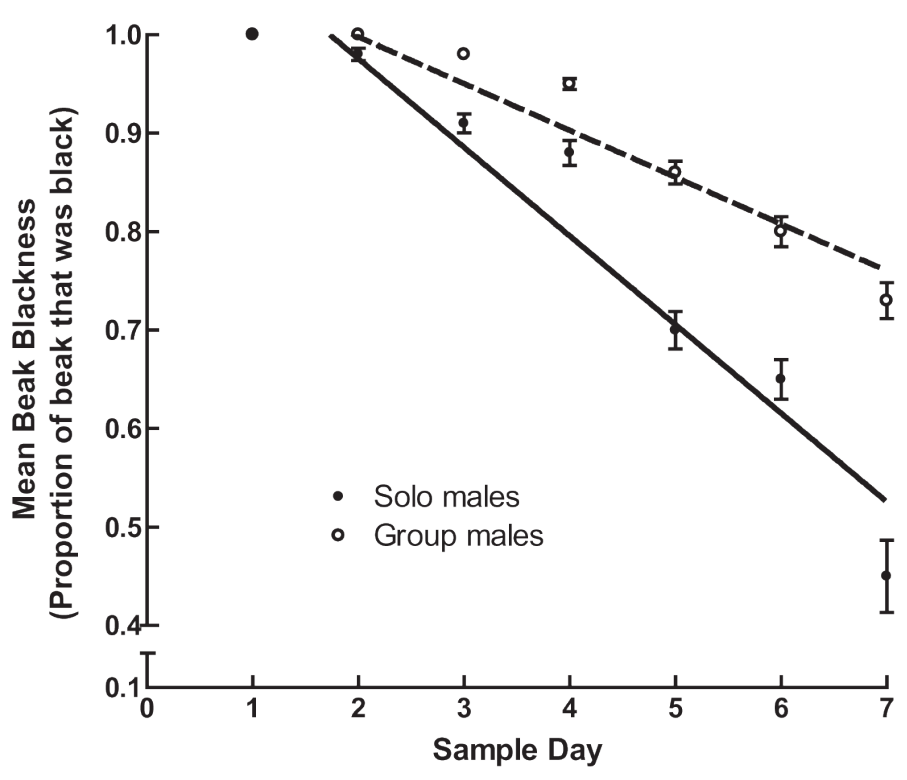

Figure 2. Mean beak blackness of captive male House Sparrows during each sample day for each social environment. Sample 1 = day of housing assignment, 26 May 2006. Beak blackness was measured weekly. Means \pm SE are presented. Trend lines from linear regression of mean beak blackness regressed on day of sampling

during the experiment for both "Solo" $(r=-0.96, \mathrm{n}=7, P<0.001)$ and "Group" males $(r=-0.95, \mathrm{n}=7, P<0.001)$ (Fig 2). Note that mean beak blackness did not differ between "Solo" and "Group" males until sample day 2. Mean beak blackness of both "Solo" and "Group" males declined during the experiment ("Solo" males: $y=$ $1.16-0.09 x, F_{1,5}=59.77, P<0.001$; “Group" males: $\mathrm{y}=1.09-0.05, F_{1,5}=51.21, P<$ 0.001 ; Fig. 2), but declined more rapidly in "Solo" males (comparison of slopes; $F_{1,10}$ $=10.06, P=0.01)$. Cage had a significant effect on beak blackness $\left(F_{6,42}=11.14, P<\right.$ 0.001) for "Group" males.

\section{DISCUSSION}

We housed male House Sparrows either individually ("Solo" males) or in groups of three ("Group" males) to test whether social environment affects the black coloration of their beaks, a secondary sexual characteristic in this species. We found that beak blackness decreased more rapidly in "Solo" males. Because beak blackness in House Sparrows is positively correlated with circulating T levels (Keck 1934, Pfeiffer et al. 1944, Witschi 1961), it is difficult to escape the conclusion that T levels declined more rapidly in males that lacked physical contact with other sparrows. 
"Solo" males weighed significantly more than did "Group" males at the end of the experiment (Fig. 1). This was likely due to initial conditions because, by chance, "Solo" males weighed significantly more at housing assignment than did "Group" males. However, social environment probably did not differentially stress males in ways that affected mass because sampling day did not have a significant effect on mass within each treatment.

It is unlikely that the declines in beak blackness (Fig. 2) were caused by the type and amount of food we provided for sparrows. We do not think that the amount of food available to males affected their beak blackness for two reasons. First, Kendeigh (1941) showed experimentally that feeding level had little effect on testes development in captive House Sparrows. Second, Meijer and Schwabl (1989) showed experimentally that access to food by captive male Kestrels (Falco tinnunculus) had little effect on T levels. Moreover, the sparrows during our experiment were fed a commercial product specifically designed for birds and we supplemented it with a product designed to enhance breeding by caged birds. Captive males were fed ad libitum, so the declines in beak blackness were probably not due to a lack of food, although there may have been competition for food amongst "Group" males.

We hypothesize that the gradual beak depigmentation we observed was due to decreasing T levels over the course of the experiment because of the direct relationship between beak blackness in male House Sparrows and T levels (Keck 1933, 1934, Pfeiffer et al. 1944). Beak depigmentation occurred in both "Solo" and "Group" males and, consistent with our predictions, was more rapid in "Solo" males (Fig. 2). Furthermore, the progression of beak color from black to horn-colored at the end of the breeding season (Lowther and Cink 1992) directly parallels gonadal inactivation and testes regression (Lal and Thapliyal 1982). This pattern is consistent with our observations during a previous study that showed that beak depigmentation was associated with testicular atrophy in captive male House Sparrows (Lombardo and Thorpe 2009). We therefore infer that the T levels declined and the testes of both "Solo" and "Group" males atrophied in this study. The greater decrease in mean beak blackness of "Solo" males suggests that T levels declined to a greater extent in "Solo" than in "Group" males. These hypotheses can be directly tested with hormone assays. We attempted but unfortunately failed to measure T levels.

Thyroid hormones may also play an important role in beak color in sparrows of the genus Passer because thyroid hormones may help regulate steroid hormone synthesis (Lal and Thapliyal 1982). Lal and Pathak (1987) showed that thyroidectomized male Tree Sparrows (Passer montanus) lost beak color that could be restored by thyroxine treatment.

Our results were somewhat surprising because our captive sparrows should have maintained black beaks throughout our experiment which occurred during the middle of the House Sparrow breeding season in Michigan (Berger 1957). We infer that being 
held in captivity resulted in a decrease in beak blackness because all wild males at the time of the experiment had black beaks.

The observation that beak depigmentation in "Group" males occurred more slowly than in "Solo" males is also consistent with the Challenge Hypothesis (Wingfield et al. 1990). Compared to "Group" males, "Solo" males had no direct opportunities for malemale agonistic interactions. Both "Solo" and "Group" males were unable to compete for females, but were in auditory and visual contact with females housed in nearby cages. Therefore, the declines in beak blackness were surprising because male exposure to females typically results in elevated T levels in both free-ranging male birds (Runfeldt and Wingfield 1985, Meijer and Schwabl 1989) and males caged with females (Feder et al. 1977, Dufty and Wingfield 1986, Meijer and Schwabl 1989, Pinxten et al. 2003). Note that in all of these studies, males had the opportunity to have had physical contact with females.

There were significant cage effects on beak blackness for "Group" males leading us to infer that the social interactions that may have influenced $\mathrm{T}$ levels varied among cages. McGraw et al. (2003) showed experimentally that more aggressive captive male House Sparrows housed in triads during molt grew larger bibs implying that they had higher $\mathrm{T}$ levels than did males that grew smaller bibs. The black chin bib of male House Sparrows is a secondary sexual characteristics whose expression is positively correlated with $\mathrm{T}$ levels during molt (Møller 1988.) Therefore, the slower rate of beak depigmentation in "Group" males in our study may have been related to aggressive interactions over food and positions in the dominance hierarchy in each cage which may have resulted in higher T levels for longer, on average, in "Group" males. Unfortunately, we did not observe "Group" males frequently enough to determine the position of individual males in each cage's dominance hierarchy, but we predict that the most dominant male in each group cage would have delayed beak depigmentation the longest.

Secretion of the steroid hormone corticosterone (CORT) in House Sparrows is associated with the stress of capture, confinement in small cages (Lynn and Porter 2008), and handling (Rich and Romero 2001, Romero and Romero 2002), so it is possible that captivity stressed both "Solo" and "Group" males so that beak blackness decreased (Wingfield 1983, Wingfield and Moore 1987). The stress of captivity in our study may also have been exacerbated by small cage size (Cancione et al. 2002, Lynn and Porter 2008). Indeed, short-term confinement ( $\leq 90 \mathrm{~min}$ ) in wire cages smaller $(18 \times 18 \times 18 \mathrm{~cm})$ than those used in our study resulted in a marked CORT response in House Sparrows (Lynn and Porter 2008). In addition, weekly handling may have contributed to stress levels of both "Solo" and "Group" males. However, even if weekly handling increased stress in our captive sparrows, it does not explain why beak blackness decreased faster and to a greater degree in "Solo" than in "Group" males.

Mitchell and Hayes (1973) and Moreno-Rueda and Soler (2002) bred House Sparrows in captivity, albeit with modest success. In each case, the sparrows were 
able to fly freely with other sparrows of both sexes in a relatively large outdoor aviary. Furthermore, breeding success of House Sparrows housed in flocks typically exceeds that of birds housed as isolated pairs (Anderson 2006). Our results suggest that just seeing or hearing other House Sparrows in nearby cages was not sufficient for our captive males to maintain breeding season beak blackness. The more rapid beak depigmentation in "Solo" males is consistent with our prediction that they would lose beak color faster than would "Group" males and suggests that physical contact may help maintain breeding season T levels in male House Sparrows.

The presence of a nest box and nesting material in the cages did not stimulate maintenance of beak blackness in either "Solo" or "Group" males. In European Starlings, a nest box is a more important stimulus for $\mathrm{T}$ production than either male-male or female-male interactions (Gwinner et al. 2002).

In conclusion, our results show that captivity negatively affected beak blackness in male House Sparrows. The more rapid beak depigmentation we observed in "Solo" males implies that male House Sparrows may require physical interactions with other sparrows to maintain breeding season beak color. We recommend experiments designed to differentiate between the effects of male-male and male-female interactions in maintaining breeding season beak color in male House Sparrows.

\section{ACKNOWLEDGEMENTS}

This study was supported by NSF IOB-0525583, a McNair Scholars award to S. Colpetzer, and the Department of Biology at Grand Valley State University (GVSU). R. Pinxten, S. Laucht, anonymous reviewers, and especially I.R.K. Stewart provided useful comments on earlier versions of the manuscript. We were assisted in the field and laboratory by D. Diekema. This project was approved by the Institutional Animal Care and Use Committee at GVSU.

\section{REFERENCES}

Anderson T.R. 2006 - Biology of the ubiquitous House Sparrow: from genes to populations Oxford University Press, New York, NY.

Berger A.J. 1957 - Nesting behavior of the House Sparrow - Jack Pine Warbler, 35:86-92.

Cancione V., Hayden T.J., Rowe K., Goymann W. 2002 - The stress response of European Stonechats depends on the type of stressor - Behav., 139:1303-1311.

Dufty, Jr., A.M., Wingfield J.C. 1986 - The influence of social cue on the reproductive endocrinology of male Brown-headed Cowbirds: field and laboratory studies - Horm. Behav., 20:222-234.

Feder H.H., Storey A., Goodwin D., Reboulleau C., Silver R. 1977 - Testosterone and $5 a$-dihydrotestosterone levels in peripheral plasma of male and female Ring Doves (Streptopelia risoria) during the reproductive cycle - Biol. Reprod.,16:666-677.

Gwinner H., Van't Hof T., Zeman M. 2002 - Hormonal and behavioral responses of starlings 
during confrontations with males or females at nest boxes during the reproductive season - Horm. Behav., 42:21-31.

Haase E. 1975 - The effects of testosterone propionate on secondary sexual characters and testes of House Sparrows, Passer domesticus- Gen. Comp. Endocrin., 26:248-252.

Hegner R.E., Wingfield J.C. 1984 - Social facilitation of gonadal recrudescence - J. Steroid Biochem., 20:1549.

Hegner R.E., Wingfield J.C. 1986 - Gonadal development during autumn and winter in House Sparrows - Condor, 88:269-278.

Hirschenhauser K., Oliveira R.F. 2006 - Social modulation of androgens in male vertebrates: meta-analysis of the challenge hypothesis - Anim. Behav., 71:265-277.

Johnson A.L. 1986 - Reproduction in the male - In: Avian Physiology, Ed. P.D. Sturkie - SpringerVerlag, New York, NY:432-451

Keck W.N. 1933 - Control of bill color of the male English Sparrow by injections of male hormone - Proc. Soc. Exper. Biol. Med., 30:1140-1141.

Keck W.N. 1934 - The control of secondary sex characteristics in the English sparrow, Passer domesticus Linnaeus - J. Exper. Zool., 190:137-153.

Kendeigh S.C. 1941 - Length of day and energy requirements for gonad development and egglaying birds - Ecology, 22:237-248.

Kinnear P.R., Gray C.D. 2004 - SPSS 12 made simple - Psychology Press, New York, NY.

Lal P., Pathak V.K. 1987 - Effect of thyroidectomy and L-thyroxine on testes, body weight and bill color of the Tree Sparrow Passer montanus - Indian J. Exper. Biol., 25:660-663.

Lal P., Thapliyal J.P. 1982 - Role of thyroid in the response of bill pigmentation to male hormone of the House Sparrow, Passer domesticus - Gen. Comp. Endocrinol., 48:135-142.

Lombardo M.P., Thorpe P.A. 2009 - Captivity affects sperm production, testes size, and beak color in House Sparrows (Passer domesticus) - Int. Studies of Sparrows, 33:5-16.

Lowther P.E., Cink C.L. 1992 - House Sparrow. In: The birds of North America, Eds. A. Poole, P. Stettenheim, F. Gill - The Academy of Natural Sciences, Philadelphia, PA, The American Ornithologists' Union, Washington, D.C.

Lynn S.E., Porter A.J. 2008 - Trapping initiates stress response in breeding and non-breeding House Sparrows Passer domesticus: implications for using unmonitored traps in field studies - J. Av. Biol., 39:87-94.

McGraw K.J., Dale J., Mackillop E.A. 2003 - Social environment during molt and the expression of melanin-based plumage pigmentation in male House Sparrows (Passer domesticus) - Behav. Ecol. Sociobiol., 53:116-122.

Meijer T., Schwabl H. 1989 - Hormonal patterns in breeding and nonbreeding Kestrels, Falco tinnunculus: field and laboratory studies - Gen. Comp. Endocrinol., 74:148-160.

Mitchell C.J., Hayes R. O. 1973 - Breeding House Sparrows, Passer domesticus in captivity Ornithol. Monog., 14:39-48.

Møller A.P. 1988 - Badge size in the house sparrow Passer domesticus. Effects of intra- and intersexual selection - Behav. Ecol. Sociobiol., 22:373-378.

Moreno-Rueda G., Soler M. 2002 - Cría en cautividad del gorrión común Passer domesticus Ardeola 49:11-17.

Pfeiffer C.A., Hooker C.W., Kirschbaum A. 1944 - Deposition of pigment in the sparrow's bill in response to direct application as a specific and quantitative test for androgen - Endocrinol., 34:389-399.

Pinxten R., deRidder E., Eens M. 2003 - Female presence affects male behavior and testosterone levels in the European Starling (Sturnus vulgaris) - Horm. Behav., 44:103-109.

Rich E.L., Romero L.M. 2001 - Daily and photoperiod variations of basal and stress-induced 
corticosterone concentrations in House Sparrows (Passer domesticus) - J. Comp. Physiol. B, 171:543-547.

Romero L.M., Romero R.C. 2002 - Corticosterone responses in wild birds: the importance of rapid initial sampling - Condor, 104:129-135.

Runfeldt S., Wingfield J.C. 1985 - Experimentally prolonged sexual activity in female sparrows delays termination of reproductive activity in their untreated males - Anim. Beh., 33:403-410.

SPSS. 2002 - SPSS for Windows, Version 10.0. SPSS, Chicago, IL.

Wingfield J.C. 1983 - Environmental and endocrine control of avian reproduction: an ecological approach - In: Avian Endocrinology: Environmental and Ecological Perspectives, Eds. S.I. Mikami, K. Homma, M. Wada - Japan Scientific Societies/Springer, New York: 265-288.

Wingfield J.C. 1985 - Environmental and endocrine control of territorial behavior in birds - In: The endocrine system and the environment, Eds. B.K. Follett, S. Ishii, A. Chandola - Science Society Press, Tokyo, Japan: 265-277.

Wingfield J.C., Ball G.F., Dufty Jr., A.M. Hegner R.E, Ramenofsky M. 1987 - Testosterone and aggression in birds - Am. Sci., 75:602-608.

Wingfield J.C., Farner D.S. 1980 - Control of seasonal reproduction in temperate-zone birds Progress Reprod. Biol., 5:62-101.

Wingfield J.C., Farner D.S. 1993 - Endocrinology of reproduction in wild species - In: Avian Biology, Eds. D.S. Farner, J.R. King, K.C. Parkes - Academic Press, New York, NY: 263-327.

Wingfield J.C., Hegner R.E., Dufty Jr., A.M., Ball G.F. 1990 - The 'challenge hypothesis': theoretical implications for patterns of testosterone secretion, mating systems and breeding strategies - Am. Nat., 136:829-846.

Wingfield J.C., Moore M.C. 1987 - Hormonal, social and environmental factors in the reproductive biology of free-living male birds - In: Psychobiology of Reproductive Behaviour: An Evolutionary Perspective, Ed. D. Crews - Prentice-Hall, Englewood, NJ: 149-175.

Witschi E. 1961 - Sex and secondary sexual characters - In: Biology and Comparative Physiology of Birds, Ed. A.J. Marshall - Academic Press, New York, NY: 115-168. 